\title{
Development of Consumer Perception Index for assessing greywater reuse potential in arid environments
}

\author{
Md Shafiquzzaman', Husnain Haider', Saleem Saleh AISaleem', Abdul Razzaq Ghumman' and Rehan Sadiq² \\ 'Civil Engineering Department, College of Engineering, Qassim University, Buraydah, Qassim, Saudi Arabia \\ ${ }^{2} S$ Chool of Engineering, University of British Columbia (Okanagan), Kelowna, British Columbia, Canada
}

\begin{abstract}
Arab countries are primarily situated in arid environments and face serious water scarcity challenges due to growing populations, urbanization, and climate change impacts. Reusing greywater, if adequately treated at the point of generation, poses less human health risk as compared to blackwater reuse. Consumers have several reasons for being unwilling to reuse greywater, including potential health risk, religious and cultural concerns, and feeling uncomfortable. There are several possible reuse applications of treated greywater, such as watering plants, floor cleaning, landscaping, toilet flushing, etc. Therefore, it is important to assess consumer perceptions about greywater reuse before its implementation in any region. In this research, a framework based on greywater reuse indicators (GWRI) was developed to assess consumer perceptions before and after introducing low-cost treatment (LCT). Later the framework was implemented for Muscat, Oman. A questionnaire survey was carried out with 110 households located in diverse socioeconomic settings to collect data about general demographics, existing water uses, water sources, greywater applications (after LCT), and in-house plumbing systems. Seven key GWRI were estimated and aggregated to develop an overall consumer perception index (CPI). The study results revealed that CPI improved significantly from 'very low' to 'high' after introducing LCT. However, governments should provide financial assistance to consumers for improving in-house plumbing systems, based on detailed investigations. The study revealed that the CPI can be applied across the globe and can save time and effort for municipal managers, engineers, and policy makers by providing information that will enable effective decision-making.
\end{abstract}

Keywords: consumer perception, greywater reuse, low-cost treatment, interview surveys, arid environment, water quality

\section{INTRODUCTION}

Most Arab countries are facing challenges of water shortages due to growing populations, increasing urbanization, climate change impacts, and decreasing precipitation. With these countries being located along coastlines, a large percentage of treated or untreated wastewater in these countries is being discharged into the sea, for instance, $60 \%$ in Morocco, $80 \%$ in Lebanon (80\%), and 95\% in Dubai. According to the Arab Countries Water Utility Association (ACWUA), almost all of the countries, with the exception of Lebanon where adequate freshwater sources are available, are taking wastewater reuse into consideration to alleviate the current situation of water scarcity (ACWUA, 2010). Municipal wastewater primarily consists of blackwater (originated from toilet flushing) and greywater, (used water from kitchen sinks, bathing, and laundry) (Morel and Diener, 2006). Although the proportion of blackwater is relatively low in the entire municipal wastewater load, it contains major components of organic and bacteriological contamination (Paulo, 2013). Reusing greywater poses a lower human health risk as compared to blackwater reuse after adequate treatment at the point of generation, e.g., homes, commercial centres, parks, and other public institutions.

Being less polluted than blackwater and comprising around $70 \%$ of total sewage flow, greywater holds an immense potential for reuse (Hernández et al., 2007). Greywater separation at source, followed by low-cost treatment, e.g., septic tanks, roughing filters, constructed wetlands, etc., could be a sustainable solution to overcome

\footnotetext{
* To whom all correspondence should be addressed.

e-mail: husnain@qec.edu.sa

Received 15 July 2017, accepted in revised form 15 October 2018.
}

existing challenges of water scarcity and to conserve limited freshwater sources around the world (Chanakya et al., 2013). Due to persisting drought conditions in Gulf countries, consumers are forced to use tap water for watering plants (in home gardens) and for other outdoor applications (Friedler and Lahav, 2006). In addition to water conservation, greywater separation and reuse can reduce the total volume of wastewater and thus the cost of final treatment (Santos et al., 2012). However, this is only possible if the greywater undergoes adequate and safe treatment in order to ensure the quality for non-potable applications. Further, if sufficient and advanced treatment is applied to the greywater in order to improve its quality, the countries suffering from limiting freshwater supplies in different parts of the world may have a pragmatic option of reusing greywater for certain applications (Gibson and Apostolidis, 2001).

For greywater reuse, prior implementation of lowcost treatment (LCT) at the source, and assessment of public (consumers) perception and acceptance is of utmost importance. Consumers' unwillingness to reuse treated greywater might diminish the possibility of its application. There might be several reasons for showing unwillingness to reuse greywater, such as: (i) lack of knowledge about lowcost treatment, (ii) inadequate information about possible applications of greywater reuse, (iii) religious concerns, and (iv) aesthetics, e.g., feeling uncomfortable. Furthermore, there are several applications of reuse, such as watering plants, floor cleaning, toilet flushing, etc. Some consumers may be willing to reuse greywater for a specific application while others may be interested in more than one application. Thus, assessing consumer perceptions is an important task in order to plan, construct, and operate sustainable wastewater reclamation and reuse facilities in arid regions. 
Several studies have been reported in literature that aimed, based on questionnaire surveys, to assess consumer perceptions of water reuse applications in different countries (Friedler and Lahav, 2006; Buyukkamacia and Alkanba, 2013; Troy, 2006; Domènech and Saurí, 2010; Kantanoleon et al., 2007, Pinto and Maheshwari, 2010). Greywater generated from kitchens also contains organic material and oils and fats which need complex and expensive biological treatment in order to meet reuse standards (Paulo, 2013; Morel and Diener, 2006; Palmquis and Hanaeus, 2005; Ottoson and Stenstrom, 2003). Some studies revealed quite high percentages for respondents' willingness to reuse greywater after treatment. In a survey conducted in Sydney (Australia), more than $90 \%$ of respondents agreed to reusing treated greywater for garden watering (landscaping) and toilet flushing (Marks, 2004).

Domènech and Saurí (2010) investigated public concerns about reuse of treated greywater in terms of health and environmental risks in the city of Barcelona, Spain. Their study showed that $84 \%$ of respondents were well aware of the benefits of the system and felt assured that the treated greywater posed no or very low health risk. Countries in arid regions, such as Saudi Arabia, Kuwait, Cyprus, Muscat, and Jordan, can potentially reuse greywater, after complying with regional regulations and standards, for non-potable purposes, and possibly reduce the pressure on their fresh-water supplies or desalination facilities. However, there is a need for necessary support and encouragement for the reuse of greywater, particularly through clear guidelines, technical specifications and incentives for sustainable reuse of greywater (Al-Jayyousi, 2003; Abusam, 2008; Buyukkamacia and Alkanba, 2013).

The concept of consumer acceptance in the water industry has been well-recognized in Techneau (an integrated project funded by the European Commission), and is described as 'the consumer's willingness or ability to receive and to tolerate' (Techneau, 2007 p. 6). This concept of acceptance is related to consumer satisfaction about the performance of a service or a facility. Water utilities or private suppliers establish a level of service based on how much deviation the consumers can accept from the desired performance (Haider et al., 2016a). Acceptance in this case is generally measured through interviews and surveys after providing services over a given assessment period. In this research an effort is made to assess the change in perception (i.e., the way a person thinks about or understands something), before and after introducing a sustainable solution for greywater reuse (i.e., LCT) to the consumers. Methodology developed in this paper will be applicable to assess the feasibility of greywater (excluding kitchen water) reuse in arid environments or elsewhere, prior to actual implementation of the system of greywater reuse with low-cost treatment.

The interview-based methodologies used in the abovementioned studies reported their results either in terms of '\% of the respondents agreed upon' or ' $\%$ of the respondents opposed to' a certain opinion inquired after; for instance, 'Are you willing to use greywater for watering your gardens?' Sometimes, there are several questions asked about different applications or about the reasons for unwillingness to reuse greywater. Moreover, consumer perception can be changed after providing consumers with guidance about: (i) water scarcity issues, (ii) benefits of greywater reuse towards water conservation, and (iii) simplicity of LCT technologies. These findings can certainly provide valuable evidence about consumer perceptions towards greywater reuse; nevertheless such a large number of findings needs to be aggregated to facilitate decision making, i.e. by offering decision makers one final answer.

To the best of our knowledge, consumer perceptions of greywater reuse have not been assessed, to date, in terms of an index that will enable an inclusive appraisal. In this research, a framework is developed to assess consumer perception using an indicator-based approach. Firstly, key indicators of greywater reuse are developed to capture the applications of greywater and reasons for unwillingness. These indicators are then aggregated to develop an overall consumer perception index (CPI). This index will certainly be very useful for the general public, media, operational staff of water utilities, municipal managers, policy makers, experts from academia and expert practitioners. Presently, consumers in Oman do not frequently reuse wastewater. There have only been a few reuse projects and an in-depth and detailed assessment of public opinion does not exist on water reuse applications in the country. Hence, the proposed framework was applied to Muscat City in Oman to demonstrate its applicability in arid environments.

\section{METHODOLOGY}

\section{Consumer perception assessment framework}

The framework developed in this research, to assess the change in consumer perception before and after introducing the LCT for greywater reuse, is presented in Fig. 1. The LCT for greywater reuse, introduced to the consumers, was

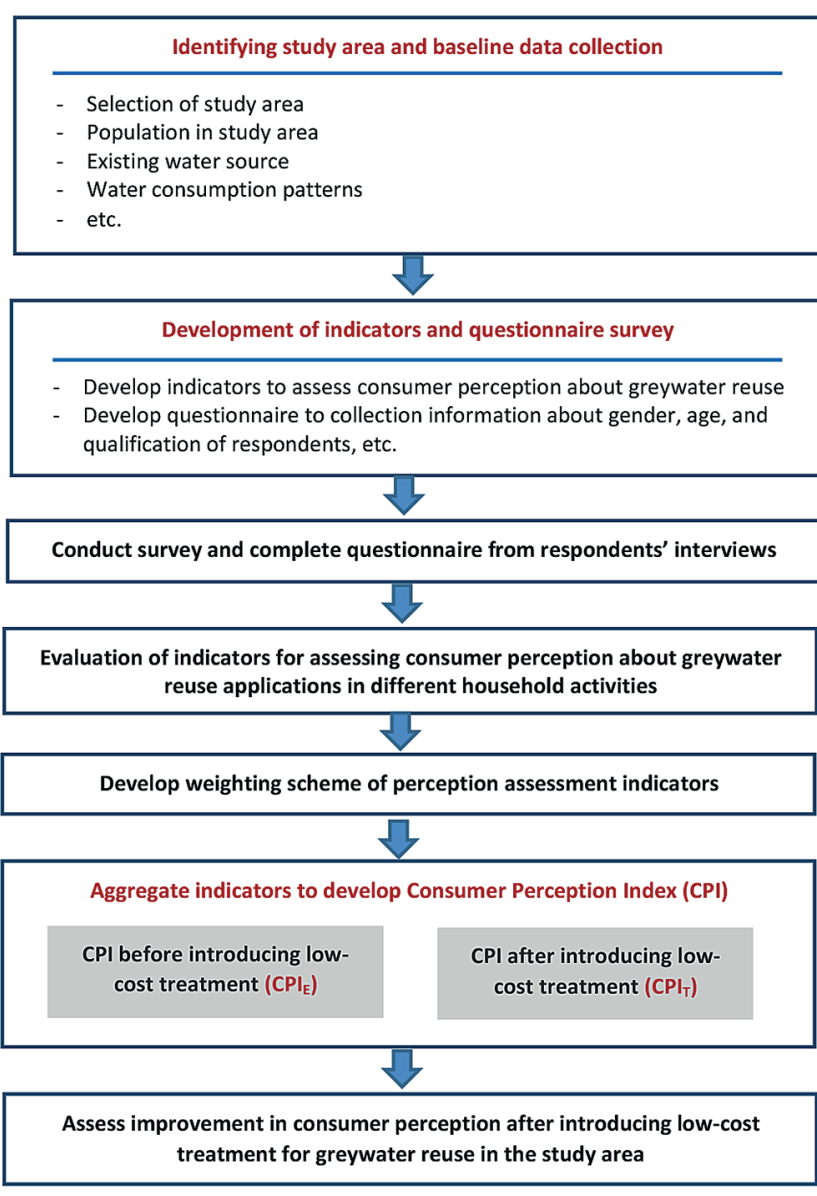

Figure 1

Consumer perception assessment framework for greywater reuse 
intended to consist of sedimentation or coarse filtration followed by disinfection. Such simple greywater treatment technologies, although providing limited removal of organics and solids, have been shown to be effective at household level for providing adequate water quality for reuse in gardens, floor washing, and toilet flushing. For details, interested readers are referred to Pidou et al. (2007) and Moreland Diener (2006).

Development of the framework was initiated with identification of a representative urbanized residential area in Oman. General information was collected about the population, water source, standard of living, etc. Seven indicators were developed to assess consumer perceptions in the subsequent step. These indicators can assess the level of application of greywater reuse in different household activities. A questionnaire was developed followed by a survey to collect the required information from selected respondents in the study area. First, the questionnaire was filled in before introducing the LCT to the respondents, with the objective to essentially evaluate the existing scenario, i.e., almost negligible application of greywater reuse, in the study area. Later, the same questions were asked after introducing the LCT to assess the improvement in customer perceptions of greywater reuse at household level. The data obtained from the survey were used to evaluate the indicators. The weighting scheme for perception indicators was established using Simo's method, described in a following section. Normalized values of indicators were then aggregated to develop the consumer perception index. Using the index, an overall improvement level in consumer perception about greywater reuse was assessed after introducing the low-cost treatment.

\section{Development of consumer perception assessment indicators}

Consumer perception can be described in terms of: (i) a psychological factor which influences their purchase behaviour, and (ii) a process by which individuals interpret the information received from the environment about the product (Wee et al., 2014). Actually, consumer perception affects their actions, product selection, and buying habits, etc.; thus perception can impact strategic decision making because consumers decide based on their experience and knowledge instead of on the basis of objective reality. However, perception can be changed about a product or a service, such as LCT in this study for greywater reuse, if the providers effectively introduce their services to the consumers.

In this research, an index-based approach is used to assess 'how do the perceptions of consumers change after being introduced to a possible intervention in their existing system?' In order to develop the consumer perception index, seven greywater reuse indicators (GWRI) were developed (see Table 1). It can be seen that the first five indicators appraise the level of application of greywater reuse, e.g., \% of people using GW for floor cleaning, etc., while the last two indicators provide information on the reasons for unwillingness to reuse greywater for a given scenario in a given assessment period. Depending on specific environmental conditions and local practices, additional indicators can be added.

\section{Development of questionnaire survey}

A questionnaire (Table 2) was designed to investigate the perceptions of consumers toward the reuse of greywater, after

\begin{tabular}{|l|l|}
\hline \multicolumn{2}{|c|}{$\begin{array}{c}\text { TABLE 1 } \\
\text { Greywater Reuse Indicators (GWRI) developed } \\
\text { in present study }\end{array}$} \\
\hline No. & \multicolumn{1}{c|}{ Description } \\
\hline Indicators to assess application of greywater reuse \\
\hline GWRI $_{1}$ & \% of people using grey water (GW) \\
\hline GWRI $_{2}$ & \% of people using GW for watering plants (WP) \\
\hline GWRI $_{3}$ & \% of people using GW for floor cleaning (FC) \\
\hline GWRI $_{4}$ & \% of people using GW for flushing toilets (FT) \\
\hline GWRI $_{5}$ & \% of people using GW for car cleaning (CC) \\
\hline Indicators to assess unwillingness to reuse greywater $^{\text {(ndis }}$ \\
\hline GWRI $_{6}$ & \% of people not using GW due to health risk \\
\hline GWRI $_{7}$ & $\begin{array}{l}\text { \% of people not using GW due to uncomfortable } \\
\text { feeling }\end{array}$ \\
\hline
\end{tabular}

passing through a treatment system, within the household, in Muscat. The questionnaires were distributed to 110 randomly selected, but spatially well distributed, , respondents while face-to-face interviews were also conducted simultaneously (see Appendix). A total 18 questions were designed, including those requesting general information about respondents, current sources of water, existing greywater reuse applications, willingness to use greywater, reasons for unwillingness to use greywater, respondents' preferences towards greywater reuse options, and existing system of wastewater discharge. The survey was completed in 3.5 weeks, including the distribution and collection of the questionnaire surveys.

The interview took around 15 to $30 \mathrm{~min}$ for an individual household. Definitions and basic information on greywater reuse and its benefits related to water conservation were explained to each respondent before initiation of the interview. The survey data collected during the study were analysed using the Microsoft Excel 'pivot-table' tool to obtain key trends and inter-relationships of responses, for graphical representation of consumers' responses, and finally to develop the CPI. The questionnaire was developed to capture consumer perceptions of two scenarios. The first scenario represented the current practices and reservations of the consumers which led to their not using greywater, while the second scenario exemplified a hypothetical situation assuming application of treated greywater posing a reduced health risk.

\section{Development of Consumer Perception Index (CPI)}

The CPI developed by accumulating the information gathered through the questionnaire survey, in the form of greywater reuse indicators, will provide more useful information for effective decision-making and will motivate the general public to support water conservation efforts. The process to develop the index consisted of two main steps, including establishment of: (i) a weighting scheme, and (ii) an aggregation scheme. Haider et al. (2016b) developed indices for performance benchmarking of various components of smaller water utilities. They used two multicriteria analysis techniques, including Simo's method (Marzouk et al., 2014) for the weighting process, and 'Technique for Order Preference by Similarity to Ideal Solution' (TOPSIS) for the aggregation scheme. In the present research, a similar approach was adopted to develop the CPI for assessing consumer perceptions about greywater reuse in arid environments. 


\begin{tabular}{|c|c|c|}
\hline \multicolumn{3}{|c|}{$\begin{array}{l}\text { TABLE } 2 \\
\text { Baseline data collected through the questionnaire survey }\end{array}$} \\
\hline Variable & Questions/information & Possible response \\
\hline Bathing & Which water do you use for bath? & $\begin{array}{l}1=\text { tap water } \\
2=\text { rainwater } \\
3=\text { groundwater } \\
4=\text { river } / \text { canal water } \\
5=\text { other }\end{array}$ \\
\hline Laundry & Which water do you use for laundry? & $\begin{array}{l}1=\text { tap water } \\
2=\text { rainwater } \\
3=\text { groundwater } \\
4=\text { river } / \text { canal water } \\
5=\text { other }\end{array}$ \\
\hline Cooking & Which water do you use for cooking? & $\begin{array}{l}1=\text { tap water } \\
2=\text { rainwater } \\
3=\text { groundwater } \\
4=\text { river } / \text { canal water } \\
5=\text { other }\end{array}$ \\
\hline Drinking & Which water do you use for drinking? & $\begin{array}{l}1=\text { tap water } \\
2=\text { rainwater } \\
3=\text { groundwater } \\
4=\text { river } / \text { canal water } \\
5=\text { other }\end{array}$ \\
\hline Plant watering & Which water do you use for plant watering? & $\begin{array}{l}1=\text { tap water } \\
2=\text { rainwater } \\
3=\text { groundwater } \\
4=\text { river } / \text { canal water } \\
5=\text { other }\end{array}$ \\
\hline Car cleaning & Which water do you use for car cleaning? & $\begin{array}{l}1=\text { tap water } \\
2=\text { rainwater } \\
3=\text { groundwater } \\
4=\text { river } / \text { canal water } \\
5=\text { other }\end{array}$ \\
\hline $\begin{array}{l}\text { Reuse } \\
\text { (current practices) }\end{array}$ & $\begin{array}{l}\text { Currently, do you reuse water into your } \\
\text { residence? }\end{array}$ & $\begin{array}{l}1=\text { yes } \\
2=\text { no }\end{array}$ \\
\hline Source of water & If yes, which water do you reuse? & $\begin{array}{l}1 \text { = kitchen wastewater, } \\
2 \text { = bath wastewater, } \\
3 \text { = laundry wastewater }\end{array}$ \\
\hline Willingness & Willing to reuse greywater after treatment? & $\begin{array}{l}1=\text { yes } \\
2=\text { no }\end{array}$ \\
\hline Conditions & Provision for re-using greywater & $\begin{array}{l}1=\text { good quality of treated greywater } \\
2=\text { low cost and simple treatment system } \\
3=\text { no health risk } \\
4=\text { others }\end{array}$ \\
\hline Unwillingness & Reason for not willing to re-use & $\begin{array}{l}1=\text { health risk } \\
2=\text { feel uncomfortable } \\
3=\text { cultural issue } \\
4=\text { others }\end{array}$ \\
\hline Preferences & $\begin{array}{l}\text { Which daily appliance do you accept to reuse } \\
\text { treated greywater? }\end{array}$ & $\begin{array}{l}1=\text { toilet flushing } \\
2=\text { floor cleaning } \\
3=\text { car cleaning } \\
4=\text { plant watering }\end{array}$ \\
\hline
\end{tabular}

\section{Ranking of Greywater Reuse Indicators (GWRI) using Simo's method}

Initially the list of indicators was distributed to different decision makers from academia and practice having extensive experience in the field of water management. Decision makers were asked to rank the indicators in ascending order, i.e., the most important indicator should be placed at the last rank. Subsequently, the information was gathered from them and Simo's method, consisting of the following steps, was applied:

- Step 1: Construct a table consisting of 7 columns (i.e., C1 to C7) to rank the GWRI and number all the indicators in the $1^{\text {st }}$ column $(\mathrm{C} 1)$.

- Step 2: Describe all the indicators in the $2^{\text {nd }}$ column (C2). 
- Step 3: Arrange all the indicators in ascending order in the $3^{\text {rd }}$ column (C3) according to the average frequency of the ranks given by the decision makers based on the relative importance of the GWRI.

- Step 4: Rank all the indicators in ascending order in the $4^{\text {th }}$ column (C4). Give last rank (i.e., 7) to the indicator with maximum average frequency.

- Step 5: Allocate the counts of indicators in the next column (C5), i.e., 1 for each indicator.

- Step 6: Present non-normalized weights of the GWRI in the $6^{\text {th }}$ column (C6).

- Step 7: Estimate the normalized weights of all the indicators in the last column (C7).

\section{Aggregating greywater reuse indicators using TOPSIS}

TOPSIS is based on the concept of relative closeness to the most desirable value of an indicator and remoteness from the least desirable value of the same indicator. In this research, the most desirable value is $100 \%$ (when all the respondents agree to reuse greywater) for monotonically increasing indicators of application of greywater reuse. The least desirable value is selected as $1 \%$ for monotonically decreasing indicators of reasons for unwillingness to reuse greywater.

In the following, the step-by-step procedure of the TOPSIS application is presented:

Step 1:

Estimate weights of all the GWRI using Simos' method. This step has already been described in the previous section.

Step 2:

Check the units of all the indicators for normalization. All the GWRI in the present study are described as a percentage ranging between 1 and 100 so do not need to be normalized.

Step 3:

Develop the weighted matrix where the weighted value of each GWRI can be calculated with the help of the following equation:

$$
v_{i j}=w_{j} x_{i j}
$$

where: $v_{i j}$ is the weighted value of each indicator, $w_{i j}$ is the weight of the indicator, and $x_{i j}$ is the actual value of the indicator obtained from the questionnaire survey data.

Step 4:

Identify the positive-ideal solution (PIS) and the negative-ideal solution (NIS) in terms of $X^{*}$ and $X^{*}$ respectively, in terms of weighted values of the GWRI as:

$$
\begin{aligned}
X^{*} & =\left\{v_{1}^{*}, v_{2}^{*}, \ldots \ldots \ldots . ., v_{j}^{*}, \ldots \ldots . v_{n}^{*}\right\} \\
& =\left\{\left(\max _{i} v_{i j} \mid j \in J_{1}\right),\left(\min _{i} v_{i j} \mid j \in J_{2}\right) \mid i=1, \ldots \ldots \ldots, m\right\}
\end{aligned}
$$

$$
\begin{aligned}
X^{-} & =\left\{v_{1}^{-}, v_{2}^{-}, \ldots \ldots \ldots . ., v_{j}^{-}, \ldots \ldots . v_{n}^{-}\right\} \\
& =\left\{\left(\min _{i} v_{i j} \mid j \in J_{1}\right),\left(\max _{i} v_{i j} \mid j \in J_{2}\right) \mid i=1, \ldots \ldots \ldots, m\right\}
\end{aligned}
$$

where $J_{1}$ is the set of benefit attributes of consumers perception, i.e., first five indicators listed in Table 1 while $J_{2}$ is a set of cost attributes which are the last two indicators assessing consumers' unwillingness to reuse greywater.

\section{Step 5:}

Calculate the distance of each scenario from PIS and NIS. The distances of all the GWRI for a given scenario (i.e., before and after introducing low-cost treatment) are estimated by the $\mathrm{n}$-dimensional Euclidean distance. The separation (or distance) of each indicator from the PIS is calculated as:

$$
Y_{i}^{*}=\sqrt{\sum_{j=1}^{n}\left(v_{i j}-v_{j}^{*}\right)^{2}}, i=1, \ldots \ldots \ldots \ldots, m .
$$

and the distance of each GWRI from the NIS is calculated as:

$$
Y_{i}^{-}=\sqrt{\sum_{j=1}^{n}\left(v_{i j}-v_{j}^{-}\right)^{2}}, i=1, \ldots \ldots \ldots . . ., m
$$

Step 6:

Develop consumer perception index (CPI) for both scenarios by estimating similarities to the PIS with the help of the following equation:

$$
C P I_{i}^{*}=\frac{Y_{i}^{-}}{\left(Y_{i}^{*}+Y_{i}^{-}\right)}, i=1, \ldots \ldots \ldots, m .
$$

where $C P I_{i}$ is the consumer perception index for a given scenario. Finally, the result of Eq. (6) needs to be multiplied by 100 as it is a ratio.

\section{CASE STUDY OF THE CITY OF MUSCAT}

\section{Study area}

The Sultanate of Oman, located in the south east corner of the Arab Peninsula, is an arid country with a mean annual rainfall of less than $100 \mathrm{~mm}$. Figure 2 shows the location of the survey area. The Sultanate of Oman has witnessed rapid population growth and economic development in the recent past, which simultaneously threatened the limited amount of freshwater in the country. Presently, Oman is suffering through serious water scarcity issues by meeting growing agricultural, industrial, public, and domestic water demands with limited natural resources. The net annual natural recharge to groundwater was estimated to be around $1260 \times 10^{6} \mathrm{~m}^{3}$ (Abdel Rahman and Abdel-Majid, 1993).

The total water demand is around $1650 \times 10^{6} \mathrm{~m}^{3}$, out of which $90 \%$ is used to meet agricultural requirements in the country. About $51 \times 10^{6} \mathrm{~m}^{3}$ of water is annually being desalinated to meet domestic water demands and $27 \times 10^{6} \mathrm{~m}^{3}$ of treated wastewater is being reused for agricultural application. However, greywater reuse applications at domestic level have not been assessed to date. Therefore, the framework developed in above section was implemented for the case of Muscat city, Oman, to assess the perceptions of the city's residents (i.e., consumers) about greywater reuse, after being introduced to low-cost treatment. 


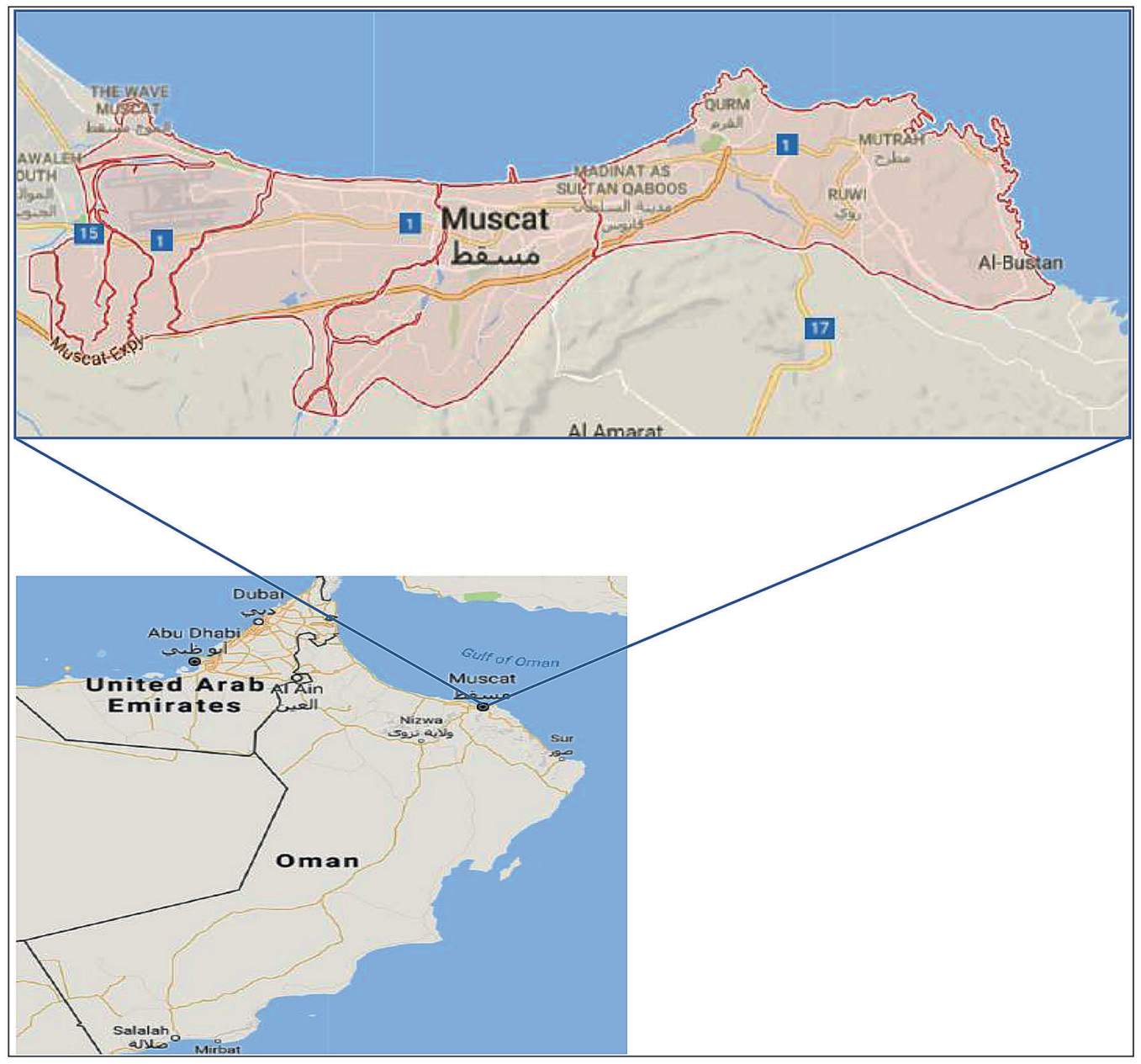

Figure 2

The location of the study area in Muscat where the questionnaire survey was conducted

\section{Questionnaire survey}

\section{Demographic information}

Demographic information of the respondents was collected before initiating the questionnaire survey. A sample size of 110 respondents was selected to conduct the survey; the sample size was limited by available resources. The survey was distributed to $52.4 \%$ male and $47.6 \%$ female respondents (see Appendix). All of the respondents were adults with an education level of at least high school or advanced. The average family size was found to be 7.14 persons per household.

\section{Statistical analysis of responses}

First, the respondents were asked about various sources of water they use to perform their different daily activities. Several activities were included in this question, such as bathing, laundry, cooking, drinking, plant watering, car cleaning and toilet flushing. Results are shown in Table 3. Tap water was found to be the primary source. It was observed from the questionnaire survey that about $77.7 \%, 78.2 \%, 80 \%, 21.5 \%, 54.0 \%, 54.9 \%$ and $97.0 \%$ of water demands for bathing, laundry, cooking, drinking, plant watering, car cleaning, and toilet flushing, respectively, were met through tap water. The results indicated that the

\begin{tabular}{|l|c|c|c|c|c|c|c|}
\hline \multicolumn{7}{|c|}{ CABLE 3 } \\
\hline Source & Bathing (\%) & Laundry (\%) & Cooking (\%) & Drinking (\%) & Landscaping (\%) & Car washing (\%) & Toilet flushing (\%) \\
\hline Tap water & $\mathbf{7 7 . 7}$ & $\mathbf{7 8 . 2}$ & $\mathbf{8 0}$ & $\mathbf{2 1 . 5}$ & $\mathbf{5 4 . 0}$ & $\mathbf{5 4 . 9}$ & $\mathbf{9 7 . 0}$ \\
\hline Bottle water & 0.0 & 0.0 & 0.0 & $\mathbf{6 7 . 8}$ & 1.8 & 0.0 & 0.0 \\
\hline Rain water & 0.0 & 0.0 & 0.0 & 0.0 & 26.6 & 1.0 & 0.0 \\
\hline Ground water & $\mathbf{1 9 . 7}$ & $\mathbf{1 9 . 1}$ & $\mathbf{1 0 . 9}$ & $\mathbf{8 . 0}$ & $\mathbf{2 . 7}$ & $\mathbf{1 7 . 8}$ & $\mathbf{1 . 6}$ \\
\hline River water & 0.0 & 1.0 & 0.0 & 0.0 & 0.0 & 1.0 & 0.0 \\
\hline Other & 2.7 & 1.8 & 9.1 & 2.5 & 0.0 & 5.3 & 1.4 \\
\hline
\end{tabular}

${ }^{*}$ filtered, mineral, desalinated 
residents of the study area rely on the water supplied by the Public Authority of Water and Electricity, Oman.

Groundwater drawn through tubewells was shown to be the second-most significant source in the study area. The survey indicated that some of the households in Muscat have their own private tubewell supply to meet their daily water requirements. Bottled water was found to be the primary source of drinking water for about $68 \%$ of the population. $47.4 \%$ of the bottles were small-sized with $600 \mathrm{~mL}$ capacity, 35.2\% were medium-sized bottles with $1.5 \mathrm{~L}$ capacity, and around $17.4 \%$ of the bottles were large-sized with $20 \mathrm{~L}$ capacity. This pattern of consumption, mainly using small-sized bottles, is not desirable when a large number of used bottles can put a burden on solid waste management systems, in addition to being a contributor to global warming. It can also be seen in Table 3 that fresh surface water sources, such as river or rain water, are almost negligible in the study area. It can be seen in the table that natural rain water has been affectively utilized for landscaping applications, i.e., $26.6 \%$ of plant watering through rain water. It is also important to note that approximately $9 \%$ and $2.5 \%$ of cooking and drinking uses were being met through mineral water, filtered water, and desalination water.

Out of 110 respondents surveyed, about $15 \%$ reused greywater regularly or at certain times during the past few years (Fig. 3a). Among the respondents who have been reusing greywater, 55\% reused greywater generated from laundry (both wash and rinse cycles), followed by $23 \%$ and $17 \%$ consumers who reused greywater originating from kitchen and toilet flushing, respectively (Fig. 3b). All of these respondents (15\% of 110 respondents) reused wastewater for gardening, or other agricultural activities, without any treatment. It was also investigated that the common practice to transfer the greywater from the source to the area of application was through an extension pipeline and/or manual bucketing. These results indicate that there is a tendency towards greywater reuse in the study area. Consumers' perceptions can be further enhanced by introducing them to the low-cost treatment system; this argument was supported by the respondents when $92 \%$ of them showed a positive response towards reuse of treated greywater.

In the next section of the questionnaire, the conditions which can enhance greywater reuse, stated by the respondents, were investigated. Among the respondents who were willing to re-use greywater, the quality of treated water and cost were found to be the pre-conditions for reuse. The results of the responses about these conditions are shown in Fig. 4. Out of 110 respondents, $78 \%$ of the respondents said that the water quality must be good. While $71 \%$ of the respondents were more concerned about the cost of the treatment system, they were interested in simple and low-cost treatment. Out of all respondents, $38 \%$ showed concern about the health risks associated with the reuse of greywater.

Survey results indicated that LCT of greywater is one of the strategies to ensure safe application of reused greywater. Treated greywater should be free from all physico-chemical and bacteriological contaminants, including turbidity, suspended solids, phosphorus, microbes and pathogens. The sources of microbes and pathogens present in the greywater are bathing and laundry (Winward et al., 2008; O'Toole et al., 2012). Greywater generated from laundry may contain high levels of phosphorus. The presence of average quantities of phosphorus in greywater does not create significant problems for plants; however, excessive quantities can become toxic to plants and can also infiltrate into groundwater through sandy soils (Christova et al., 1996). Therefore, a sustainable greywater treatment technology is essential in this region to reuse greywater in a practical and safe manner.

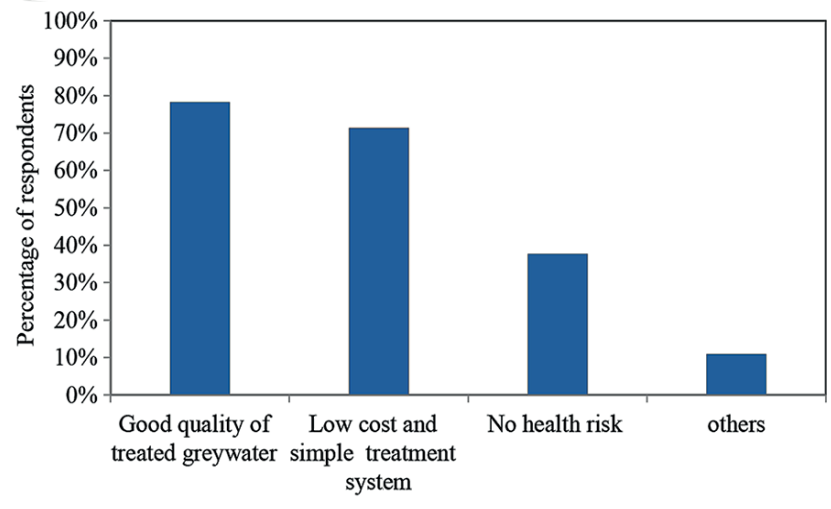

Figure 4

Pre-conditions stated by the respondents for greywater reuse $(n=110)$

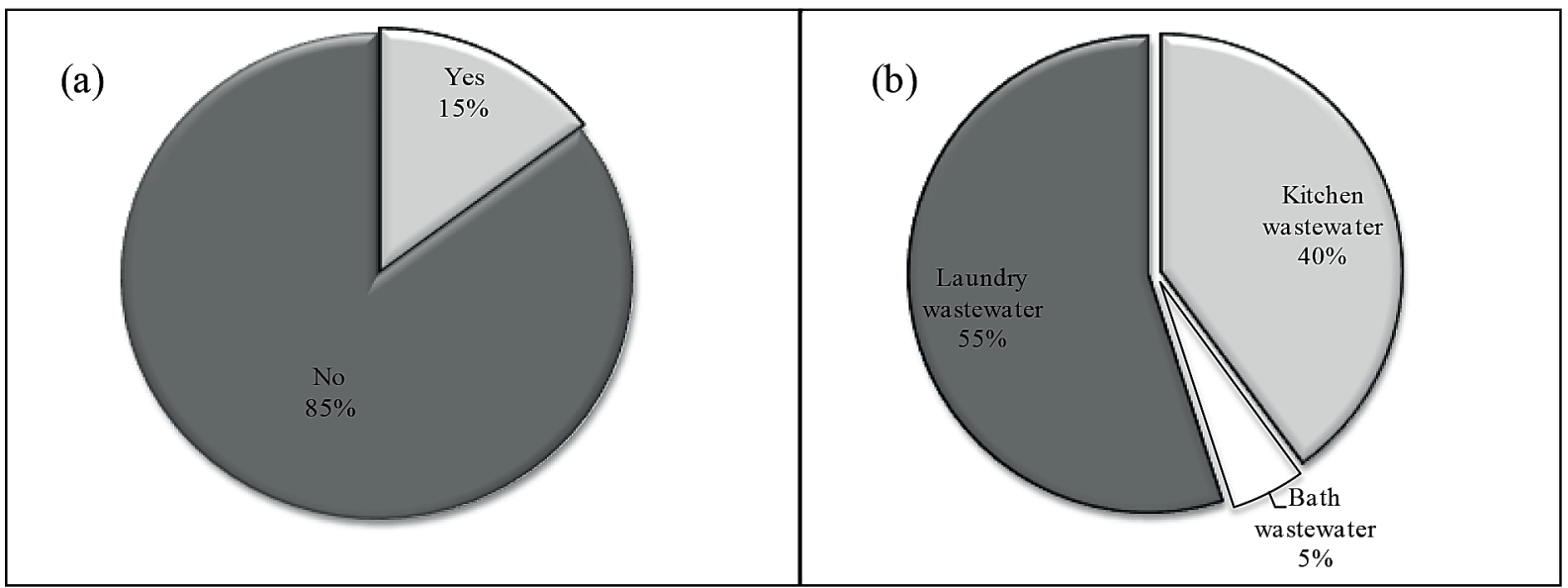

Figure 3

Greywater application statistics in the study area (a) current greywater reuse practices (number of respondents $=110$ ), $(b)$ percentage contribution of different sources of domestic greywater reused by $15 \%$ respondents 
In the subsequent question, the reasons for unwillingness to reuse greywater were asked of respondents. The results are shown in Fig. 5; around 89\% of respondents showed their concerns about the health risk and 78\% did not feel comfortable to reuse greywater. The results indicated that there is a general need for social awareness of greywater reuse in the community. Another important reason for not being willing to use greywater is the cultural issue (i.e., for $42 \%$ of respondents). The adoption of wide-scale reuse practices for greywater can be impacted by cultural barriers. In a previous study by Abusam (2008), a negative attitude was indicated towards any application of wastewater reuse in some Islamic countries. However, in this study, only $8 \%$ of respondents were opposed to the reuse of greywater. This might be due to the fact that $100 \%$ of the respondents had attained high school or higher levels of education (UNICEF, 2010). As a result, $92 \%$ of respondents were found to be willing to reuse greywater after low-cost treatment.

In the next question, the respondents were asked about the daily activities for which they would accept to reuse treated greywater. A range of water reuse options, including toilet flushing, floor cleaning, car cleaning, and plant watering were provided to the respondents. Figure 6 presents the daily applications for which the respondents readily accepted to reuse treated greywater. The highest percentage, i.e., $64.5 \%$ of the respondents, showed their willingness to reuse treated greywater for landscaping (gardening) followed by $42.7 \%$

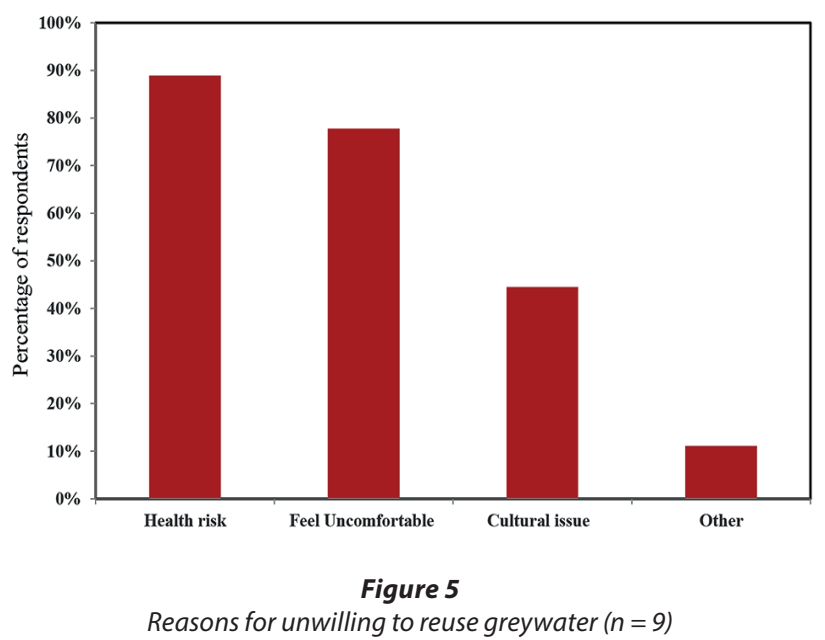

for car cleaning. Secondary preferences were given to toilet flushing and floor cleaning, i.e., $34.6 \%$. According to these results, a significant difference in consumer perceptions was observed after introducing the LCT for greywater reuse. However, other influencing factors, such as required modification to existing sewer network and in-house plumbing system, need to be investigated before actual implementation of a system of greywater reuse in the study area.

Finally, the respondents were asked about their in-house drainage network/system. It was found that around 67\% of the households have a combined system of blackwater and greywater collection which was directly connected to the municipal sewerage network. Therefore, the existing plumbing system needs to be reworked for separate collection of greywater for its effective reuse. The plumbing retrofits for the new proposed greywater system could be expensive and unaffordable for some consumers.

\section{Consumer Perception Index (CPI)}

Two scenarios to assess consumer perceptions before and after introducing LCT of greywater, using the framework -developed in Fig. 1, are described in this section. As a first step, weights for seven GWRI (listed in Table 1) were estimated using Simo's method. The results are presented in Table 4. The indicators were ranked by four decision makers having several

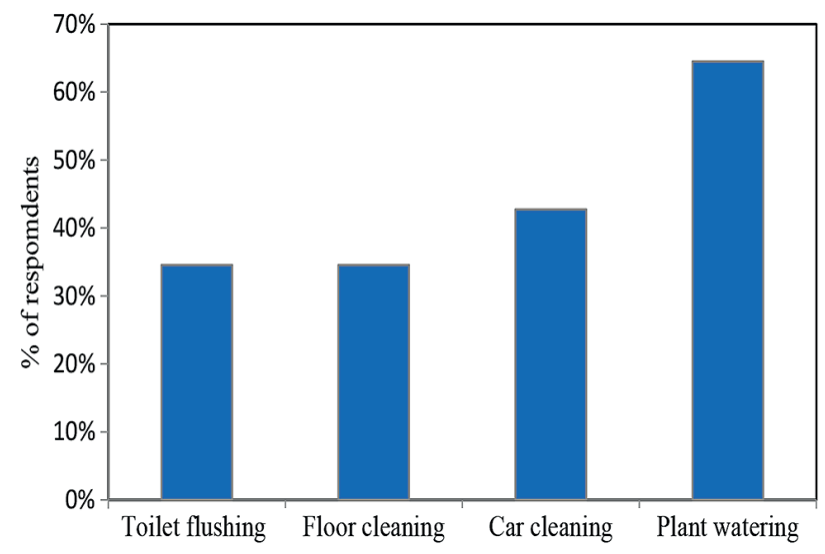

Figure 6

Respondents preferences for greywater reuse applications $(n=110)$

\begin{tabular}{|c|c|c|c|c|c|c|}
\hline \multicolumn{7}{|c|}{$\begin{array}{l}\text { TABLE } 4 \\
\text { Results of Simo's method to estimate weights of different greywater reuse indicators (GWRI) }\end{array}$} \\
\hline No. & Consumer perception indicators (CPI) & \begin{tabular}{|l|}
$\begin{array}{l}\text {AAverage }^{1} \\
\text { of GWRI } \\
\text { frequency }\end{array}$ \\
\end{tabular} & $\begin{array}{l}\text { Simo's } \\
\text { Rank }\end{array}$ & $\begin{array}{l}\text { Number } \\
\text { of factors }\end{array}$ & $\begin{array}{l}\text { Non- } \\
\text { normalized } \\
\text { weights }\end{array}$ & $\begin{array}{l}\text { Normalized } \\
\text { weights }\end{array}$ \\
\hline \multicolumn{7}{|c|}{ Indicators to assess application of greywater reuse } \\
\hline $\mathrm{GWRI}_{1}$ & $\%$ of people using grey water $(\mathrm{GW})$ & 5.50 & 6 & 1 & 6 & 0.21 \\
\hline $\mathrm{GWRI}_{2}$ & $\begin{array}{l}\% \text { of people using GW for watering plants } \\
\text { (WP) }\end{array}$ & 4.25 & 5 & 1 & 5 & 0.18 \\
\hline $\mathrm{GWRI}_{3}$ & $\%$ of people using GW for floor cleaning (FC) & 2.75 & 2 & 1 & 2 & 0.07 \\
\hline $\mathrm{GWRI}_{4}$ & $\%$ of people using GW for flushing toilets (FT) & 3.50 & 3 & 1 & 3 & 0.11 \\
\hline $\mathrm{GWRI}_{5}$ & $\%$ of people using GW for car cleaning (CC) & 2.00 & 1 & 1 & 1 & 0.04 \\
\hline \multicolumn{7}{|c|}{ Indicators to assess unwillingness to reuse greywater } \\
\hline $\mathrm{GWRI}_{6}$ & $\%$ of people not using GW due to health risk & 6.25 & 7 & 1 & 7 & 0.25 \\
\hline $\mathrm{GWRI}_{7}$ & $\begin{array}{l}\% \text { of people not using GW due to } \\
\text { uncomfortable feeling }\end{array}$ & 3.75 & 4 & 1 & 4 & 0.14 \\
\hline \multicolumn{2}{|l|}{ Total } & & & 7 & 28 & 1.00 \\
\hline
\end{tabular}

${ }^{1}$ Average of the ranks allocated by four decision makers 
years of research and professional experience in the field of water management.

After developing the weighting scheme in Table 4, the next step was to develop the consumer perception index (CPI) for both scenarios. The values of all the GWRI estimated from the questionnaire survey were arranged as the matrix presented in Table 5. Subsequently, knowing the weights of GWRIs listed in Table 4, the weighted matrix was developed using Eq. 1 in Table 6.

In the methodology section, $X^{*}$ and $X^{*}$ are defined as the PIS (100) and NIS (1) in terms of weighted values of GWRI. Their values for each indicator can be calculated with the help of Eqs 2 and 3 respectively. For example, the PIS and NIS for GWRI (i.e., \% of people using grey water) and be calculated as:

$$
\begin{aligned}
& P_{I S_{\text {GWRI1 }}}=1000.214=21.4 \\
& N I S_{\text {GWRII }}=10.21=0.21
\end{aligned}
$$

Similarly, the weighed PIS and NIS for all the GWRI were calculated and presented in Table 7.

The distance of the scores of GWRI were estimated using the n-dimensional Euclidean distance in the subsequent step. Using Eq. (4), the combined distance $\left(Y_{A}^{*}\right)$ of all the GWRI from the weighted PIS values were calculated. For example, $Y_{A}^{*}$ for the $1^{\text {st }}$ scenario, i.e., consumers perception before introducing the low-cost treatment, was found to be:

$$
\begin{aligned}
Y_{A}^{*} & \left.=\sqrt{ }\left((3.21-21.43)^{2}+3.26-17.86\right)^{2}+\cdots+(3.57-14.29)^{2}\right) \\
& =35.9
\end{aligned}
$$

Likewise, the distance from PIS for the $2^{\text {nd }}$ scenario was found to be '11.1' while the distances from NIS for the $1^{\text {st }}$ and $2^{\text {nd }}$ scenarios, using Eq. 5, are obtained as 6.5 and 35, respectively. Finally, the consumer perception index for both scenarios was calculated with the help of Eq. 6 and the results are presented in Fig. 7. It can be seen in the figure that the overall consumer perception was significantly enhanced from 'very low' to 'high' after introducing low-cost treatment. However, economic implication can be recognized as the most significant barrier, in future, for application of greywater reuse in any area. In this regard, governments can develop a plan for financial assistance for the consumers who wish to make plumbingretrofits in order to reuse treated greywater. Subsidies should be particularly be made available to the consumers living in older homes as well the low-income households, to support them to bear the cost of plumbing upgrades. These actions will encourage the reuse of greywater in the study area.

\section{CONCLUSIONS AND RECOMMENDATIONS}

Currently, countries located in arid environments, particularly Arab countries in the Gulf region, are facing challenges related

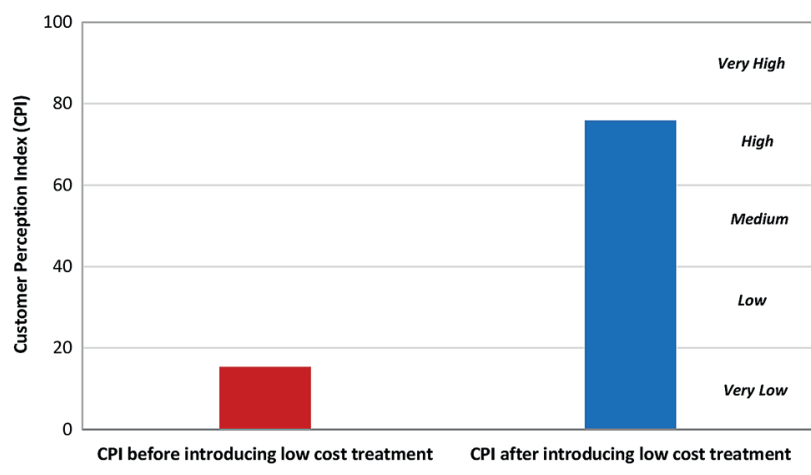

\begin{tabular}{|c|c|c|c|c|c|c|c|}
\hline \multicolumn{8}{|c|}{$\begin{array}{l}\text { TABLE } 5 \\
\text { Estimated values of GWRI through questionnaire survey }\end{array}$} \\
\hline \multirow{2}{*}{$\begin{array}{l}\text { Consumer } \\
\text { perception }\end{array}$} & \multicolumn{7}{|c|}{ Estimated values of GWRI through questionnaire survey } \\
\hline & GWRI $_{1}$ & $\mathrm{GWRI}_{2}$ & $\mathrm{GWRI}_{3}$ & $\mathrm{GWRI}_{4}$ & $\mathrm{GWRI}_{5}$ & $\mathrm{GWRI}_{6}$ & $\mathrm{GWRI}_{7}$ \\
\hline Before introducing $\mathrm{LCT}^{1}$ & 15 & 18.4 & 0 & 0 & 0 & 15 & 25 \\
\hline After introducing LCT & 92 & 64.6 & 34.6 & 34.6 & 42.7 & 92.2 & 93.2 \\
\hline
\end{tabular}

Figure 7

Consumer perception index (CPI) before and after introducing low-cost

\begin{tabular}{|c|c|c|c|c|c|c|c|}
\hline \multicolumn{8}{|c|}{$\begin{array}{c}\text { TABLE } 6 \\
\text { Weighted matrix for GWRI }\end{array}$} \\
\hline \multirow{2}{*}{ Water utility } & \multicolumn{7}{|c|}{ Weighted values of GWRI } \\
\hline & GWRI $_{1}$ & GWRI $_{2}$ & GWRI $_{3}$ & GWRI $_{4}$ & GWRI $_{5}$ & GWRI $_{6}$ & GWRI $_{7}$ \\
\hline Weights & 0.21 & 0.18 & 0.07 & 0.11 & 0.04 & 0.25 & 0.14 \\
\hline Before introducing LCT & 3.21 & 3.28 & 0.00 & 0.00 & 0.00 & 3.75 & 3.57 \\
\hline After introducing LCT & 19.71 & 11.53 & 2.47 & 3.70 & 1.53 & 23.06 & 13.31 \\
\hline
\end{tabular}
treatment in the study area of Muscat, Oman

${ }^{1}$ Low-cost treatment

\begin{tabular}{|l|c|c|c|c|c|c|c|}
\hline \multicolumn{7}{|c|}{ TABLE 7 } \\
\hline & \multicolumn{7}{|c|}{ Geighted PIS and NIS } \\
\cline { 2 - 10 } & GWRI1 & GWRI2 & GWRI3 & GWRI4 & GWRI5 & GWRI6 & GWRI7 \\
\hline PIS & 21.43 & 17.86 & 7.14 & 10.71 & 3.57 & 25.00 & 14.29 \\
\hline PNS & 0.21 & 0.18 & 0.07 & 0.11 & 0.04 & 0.25 & 0.14 \\
\hline
\end{tabular}


to diminishing water resources due to climate change impacts and rapid population growth. In this research, a framework was developed to evaluate the feasibility of greywater reuse in arid environments through a well-structured questionnaire survey. The framework also assessed the improvement in consumer perception after resolving the consumers' concerns about inadequate water quality of greywater and associated health risks by introducing low-cost treatment. The proposed framework was also applied to the case of Muscat city in Oman.

The questionnaire survey was planned for two scenarios, i.e., before and after introducing low-cost treatment. Results of the questionnaire survey conducted on more than 100 respondents in the study area revealed that significant improvement, from $15 \%$ to $92 \%$, in terms of consumer perception of greywater reuse, was noticed before and after introducing low-cost treatment, respectively. It was observed that around $65 \%$ were interested in landscape application, $42.7 \%$ for car cleaning, and $34.6 \%$ for floor cleaning as well as for toilet flushing, after the implementation of low-cost treatment.

Consumers disclosed different reasons for unwillingness to reuse greywater, such as health risk or not feeling comfortable doing so. In addition, consumers ranked their preferences for different applications of treated greywater, such as plant watering (i.e., most preferred), car washing, and floor cleaning, and flushing toilets (i.e., least preferred).

Statistical analysis of the questionnaire survey provides information about all these factors as a percentage of agreement and disagreement. In past studies, the results of such surveys in the form of large datasets have been reported as several percentage values, corresponding to each question, for developing water conservation strategies and practical decision making. In this research, all the factors are transformed into greywater reuse indictors (GWRI). Subsequently, all of these GWRI are aggregated into a new consumer perception index (CPI), using multi-criteria analysis, for efficient decision making. The study results revealed that CPI was improved from 'very low' to 'high' after introducing low-cost treatment to the respondents.

In the present research, 110 households were interviewed, given the limitation of available resources. It is recommended that the relevant authorities should conduct a more detailed survey of a larger number of households before practical implementation of this research.

Findings about existing in-house drainage networks/systems showed that that around $64 \%$ of the households had a combined collection system for blackwater and greywater. These results manifested a significant need for plumbing retrofits in the case of a relatively more complex and expansive proposed greywater system. It is recommended that governments develop strategies, codes of practice, and standards for providing financial assistance to the consumers after conducting a more detailed survey of a broader range and number of respondents.

\section{ACKNOWLEDGEMENTS}

This work was supported by Caledonian College of Engineering, Muscat, Oman, where the first author worked as a lecturer in the Department of Built and Natural Environment. This financial support is highly appreciated. We would also like to thank Ms Suhaila Mohammed Al-Subhi for her assistance in conducting of questionnaire survey. We are also grateful to all the respondents for their assistance in this research.

\section{REFERENCES}

ABDEL-RAHMAN HA and ABDEL-MAJID IS (1993) Water conservation in Oman. Water Int. 18 95-102. https://doi. org/10.1080/02508069308686155

ABUSAM A (2003) Reuse of greywater in Kuwait. Int J. Environ. Stud. 65 (1) 103-108. https://doi.org/10.1080/00207230701868204

AL-JAYYOUSI OR (2003) Greywater reuse: towards sustainable water management. Desalination 156 181-192. https://doi.org/10.1016/ S0011-9164(03)00340-0

ACWUA (2010) Arab Countries Water Utility Association (ACWUA). URL: https://acwua.org/:2010 (Accessed 18 June 2017).

BUYUKKAMACIA N and ALKANBA, HS (2013) Public acceptance potential for reuse applications in Turkey. Resour. Conserv. Recycling 80 32-35. https://doi.org/10.1016/j.resconrec.2013.08.001

CHANAKYA HN and KHUNTIA HK (2013) Treatment of gray water using anaerobic biofilms created on synthetic and natural fibers. Process Saf. Environ. Protect. 92 (2) 186-192. https://doi. org/10.1016/j.psep.2012.12.004

CHRISTOVA-BOAL D, EDEN RE and MCFARLANE S (1996) An investigation into greywater reuse for urban residential properties. Desalination 106 391-397. https://doi.org/10.1016/ S0011-9164(96)00134-8

DOMĖNECH L and SAURÍ D (2010) Socio-technical transitions in water scarcity contexts: public acceptance of greywater reuse technologies in the metropolitan area of Barcelona. Resour Conserv. Recycling 55 (1) 53-59. https://doi.org/10.1016/j. resconrec.2010.07.001

ERIKKSON E, AUFFARTH K, HENZE M and LEDIN A (2002) Characteristics of grey wastewater. Urb. Water J. 4 85-104.

FRIEDLER E and LAHAV O (2006) Centralised urban wastewater reuse: what is the public attitude. Water Sci. Technol. 54 (6-7) 423-427. https://doi.org/10.2166/wst.2006.605

GIBSON HE and APOSTOLIDIS N (2001) Demonstration, the solution to successful community acceptance of water recycling. Water Sci. Technol. 43 (10) 259-266. https://doi.org/10.2166/wst.2001.0635

HAIDER H, SADIQ R and TESFAMARIAM S (2016a) Risk-based framework for improving customer satisfaction through system reliability in small-sized to medium-sized water utilities. J. Manag. Eng. 32 (5) 04016008. https://doi.org/10.1061/(ASCE) ME.1943-5479.0000435

HAIDER H, SADIQ R and TESFAMARIAM S (2016b) Inter-utility Performance Benchmarking Model for small to medium sized water utilities: Aggregated performance indices. J. Water Resour. Plann. Manage. 142 (1) 04015039. https://doi.org/10.1061/(ASCE) WR.1943-5452.0000552

HERNÁNDEZ LL, ZEEMAN G, TEMMINK H and BUISMAN CJN (2007) Characterisation and biological treatment of greywater. Water Sci. Technol. 56 193-200. https://doi.org/10.2166/ wst.2007.572

KANTANOLEON N, ZAMPETAKIS L and MANIOS T (2007) Public perspective towards wastewater reuse in a medium size, seaside, Mediterranean city: a pilot survey. Resour Conserv. Recycling 50 (3) 282-310. https://doi.org/10.1016/j.resconrec.2006.06.006

MARKS J (2004) Back to the future: reviewing the findings on acceptance of reclaimed water, Conference Proceedings, Environ 04, Australian Water Association, 28-31 March 2004, Sydney, Australia.

MARZOUK M, HAMID S A and EL-SAID M (2015) A methodology for prioritizing water mains rehabilitation in Egypt, housing and building national research center. HBRC J. 11 114-128. https://doi. org/10.1016/j.hbrcj.2014.03.002

MOREL A and DIENER S (2006) Review of different treatment systems for households or neighbourhoods. In: Greywater Management in Low and Middle-Income Countries. Swiss Federal Institute of Aquatic Science and Technology (EAWAG), Dübendorf.

O'TOOLE J, SINCLAIR M, MALAWARAARACHCHI M, HAMILTON A, BARKER SF and LEDER K (2012) Microbial quality assessment of household greywater. Water Res. 46 (13) 4301-4313. https://doi.org/10.1016/j.watres.2012.05.001

OTTOSON J and STENSTROM AT (2003) Faecal contamination of greywater and associated microbial risks. Water Res. 37 (3) 645 655. https://doi.org/10.1016/S0043-1354(02)00352-4 
PALMQUIST H and HANAEUS J (2005) Hazardous substances in separately collected grey and black water from ordinary Swedish households. Sci. Total Environ. 348 (1-3) 151-163. https://doi. org/10.1016/j.scitotenv.2004.12.052

PAULO PL, AZEVEDO C, BEGOSSO L, ADRIANA F, GALBIATI AF and BONCZ MA (2013) Natural systems treating greywater and blackwater on-site: Integrating treatment, reuse and landscaping. Ecol. Eng. 50 95-100. https://doi.org/10.1016/j.ecoleng.2012.03.022

PIDOU M, MEMON FA, STEPHENSON T, JEFFERSON, B and JEFFREY P (2007) Greywater recycling: A review of treatment options and applications. Institution of Civil Engineers. Proc. Engineering Sustainability Conference 160 119-131. https://doi. org/10.1680/ensu.2007.160.3.119

PINTO U and MAHESHWARI BL (2010) Reuse of greywater for irrigation around homes in Australia: understanding community views, issues and practices. Urban Water J. 7 (2) 141-153. https:// doi.org/10.1080/15730620903447639

SANTOS C, TAVEIRA-PINTO F, CHENG CY and LEITE D (2012) Development of an experimental system for greywater reuse. Desalination 285 301-305. https://doi.org/10.1016/j. desal.2011.10.017

TECHNEAU (2007) Assessing consumer preferences for drinking water services - methods for water utilities. An Integrated Project Funded by the European Commission under the Sixth Framework Programme, Sustainable Development, Global Change and Ecosystems Thematic Priority Area (contract number 018320). 6 pp.

TROY WH (2006) Public perception and participation in water reuse. Desalination 187 (1-3) 115-26.

UNICEF (2010) At a glance: Oman URL:

http://www.unicef.org/infobycountry/oman_statistics.html (Accessed 18 June 2017).

WEE CS, ARIFF MSM, ZAKUAN N and TAJUDIN MNM (2014) Consumers perception, purchase intention and actual purchase behavior of organic food products. Rev. Integrated Bus. Econ. Res. 3 (2) 378-397.

WINWARD GP, AVERY LM, WILLIAMS RF, PIDOU M, JEFFREY P, STEPHENSON T and JEFFERSON B (2008) A study of the microbial quality of grey water and an evaluation of treatment technologies for reuse. Ecol. Eng. 32 (2) 187-197. https://doi. org/10.1016/j.ecoleng.2007.11.001

\section{APPENDIX}

\begin{tabular}{|l|c|}
\hline \multicolumn{2}{|c|}{ Table A1 } \\
Distribution of number of respondents interviewed with their locations \\
\hline Survey area & No. of respondents interviewed \\
\hline Al -Mawaleh & 6 \\
\hline Al-Hail & 19 \\
\hline Al-Koud & 10 \\
\hline Al- Amerat & 4 \\
\hline Al-Seeb & 3 \\
\hline Al -Mawaleh & 5 \\
\hline AL mouabila & 4 \\
\hline Muscat & 26 \\
\hline Al -Bakra & 2 \\
\hline Al-Mutrah & 2 \\
\hline Al -Hamra & 2 \\
\hline Al-Qurum & 2 \\
\hline Al-Qubra & 2 \\
\hline Al -Hamra & 2 \\
\hline Al -Doqum & 2 \\
\hline Jalan & 2 \\
\hline Al wadi Alkabeer & 2 \\
\hline Al-Kwear & 2 \\
\hline Al-Misanaa & 2 \\
\hline Al-Sahem & 2 \\
\hline Al-Athiba & 2 \\
\hline Al-Sewaiq & 2 \\
\hline Al-Abri & 2 \\
\hline Yanqul & 2 \\
\hline Total & 2 \\
\hline
\end{tabular}

